Marica Dumitrasco ${ }^{1}$

Research Institute of the University

of Bucharest (Romania).
ORIGINAL SCIENTIFIC ARTICLE doi:10.5937/ekonomika1804027D

Received: November, 12, 2018

Accepted: December, 10, 2018

\title{
INNOVATION COMPETITIVENESS OF THE COUNTRY IN GLOBAL TRADE LANDSCAPE: THE CASE OF REPUBLIC OF MOLDOVA
}

\begin{abstract}
The study highlights the importance of interaction between innovation, competitiveness and foreign trade. This study found the innovation competitiveness of a country is the main determinant for successful integration of country in the Global Value Chains $(G V C)$. The purpose of research is to study the most problematic factors that affecting the innovation competitiveness of the Moldovan economy. The study is based on the analysis of the Republic of Moldova's score and position in international indicators and rankings in correlation with the methodology of the World Economic Forum. The values of innovation, business sophistication and technological readiness factors of competitiveness between Moldova and SouthEastern Europe countries are analyzed in the paper. The study identified that the Republic of Moldova and Serbia recorded low indicators of the innovation and sophistication competitiveness in comparison with other countries of Southeast Europe. At the same time economy of Moldova follows the EU economies on the technological readiness, overcoming the Albanian and Serbian economy in the last years. The study showed that the need to raise the competitiveness by attracting foreign direct investments into research and development, information communication technologies as well as the high-value manufacturing and tradable sectors and by fully and efficiently implementing public institution reform, has become not only important but also urgent because the country is to be capable to strengthen the economic benefits that many countries have reached in past years. The results of study can be used in process of implementation of public administration reform, the elaboration of the National Program of science and innovation of the Republic of Moldova, the improving of governance the research and development in country.
\end{abstract}

Key words: regional economic integration, Global Value Chains, competitiveness, innovation, sophistication, technological readiness.

JEL classification: F 01, F14, F20, O32, O33, O57

\footnotetext{
${ }^{1}$ mdumitrasco@gmail.com
} 


\title{
ИНОВАТИВНОСТ ЗЕМЉЕ У ГЛОБАЛНОЈ ТРГОВИНИ: СЛУЧАЈ РЕПУБЛИКЕ МОЛДАВИЈЕ
}

\begin{abstract}
Апстракт
Студија осветљава значај интеракције између иновативности, конкурентности и спољне трговине. Ова студија је утврдила да је иновативност земље главна детерминанта успешне интеграције земље у глобалне ланце вредности. Циљ студије је проучавање најпроблематичнијих фактора који утичу на иновативност молдавске привреде. Студија је заснована на анализи резултата и ранга индикатора Светског економског форума Републике Молдавије. У раду се анализирају резултати стубова „Иновативност“, „Софистицираност пословања“ и „Технолошка спремност“ Молдавије и земаља југоисточне Европе. Студија је показала да Република Молдавија и Србија имају ниске показатеље иновативности и софистицираности у односу на остале земљама југоисточне Европе. У исто време, привреда Молдавије прати привреде ЕУ према достигнутом нивоу стуба „Технолошка спремност“, премашујући, албанску и српску привреду у последњих неколико година. Студија је показала да је потреба да се повећа конкурентност земље подстицањем мултинационалних компанија да улажу у науку, информационо-комуникационе технологије, као и у развој нових производа са високом додатном вредношћу постала не само важна, већ такође и хитна јер би земља била у стању да ојача економске користи које су многе земље постигле у протеклим годинама. Резултати истраживања могу да послуже креаторима јавних политика у процесу имплементације реформе јавне управе, израде Националног програма науке и иновација Републике Молдавије, унапређења управљања истраживањем и развојем.
\end{abstract}

\section{Introduction}

The important links between innovation, competitiveness and external trade have been the subject of an ongoing debate that has attracted considerable attention from both researchers and decision makers. The globalization has intensified the competition between countries. On the one hand, it is widely accepted that innovation is a key to competitiveness in the modern economy. On the other hand, factors and conditions that influence the innovative behavior and performance are largely the same as those which determine the ability of firms to compete.

Since 2010, for emerging economies and commodity-exporting economies in particular, GDP per capita has become more closely correlated with the Global Competitiveness Index's technological readiness, business sophistication, and innovation pillars than it is with the infrastructure, health and primary education, and market-related pillars (goods markets efficiency, financial market development, and labor market efficiency). (Global Competitiveness Report, 2016-2017)

In economic literature is accentuated that innovations are combined with the openness of the economy and economic integration. An open, trading economy generates incentives to innovate and invest in new technologies because firms are exposed to competition and new ideas and can benefit from the technology transfer that comes from 
imports and foreign investment. At the same time, firms can benefit from larger markets abroad (Bustos, 2011; Cassiman et al., 2010).

In this regard it should be noted, that the liberal trade policy of the Republic of Moldova is based on the multilateral and bilateral agreements within neighbor countries between which the Foreign Trade Agreement between RM and EU, Central European Free Trade Agreement (CEFTA) embracing the Southeast Europe countries not members of EU.

In this context, economic integration of the Republic of Moldova by using the potential of trade agreements will contribute to the growth of competitiveness of economy based on the knowledge and integrated into regional value chains.

This paper includes the study of the influence of global trade on the development of national economics, taking a special attention on emerging economies, and the records of the innovational competitiveness of the Moldovan economy, based on the corresponding methodology.

\section{Impact of global trade on the development of national economics}

The liberalization of foreign trade of goods is one of the main consequences of globalization, which reflects a continuous growth trend of the interdependence of the countries of the world.

A number of reputable international institutions, including the World Bank, the International Monetary Fund, the World Trade Organization, who are promoting free trade, adhere to the point of view that globalization is capable of accelerating the growth processes of the economy (IMF, WB, and WTO, 2017). It was demonstrated by the examples of number advanced and developing economies in the second part of the 20th century. But this relation is not automatic. It is the true the same that not all developing countries can benefit from the priorities of liberalization of foreign trade could be explained by their slow integration into the world technology renewed economy, not the application of trade supporting policies etc.

Despite arguments that seem undeniable, one of more disputable national trade policy topics in the period of post-World II of creation GATT/WTO till the early 1990s were that every country that is actively involved in globalization processes, in addition to obvious benefits, has many difficulties and complicated issues overcome. They caused, by the high competition on international markets, with the result that companies that are not competitive and adapted to the requirements of the day, and last but not least - those in developing countries and economies in the transition phase risk be eliminated from the market.

Agreements GATT and WTO uphold strict rules, but they contain and exceptions. It gives the rules elasticity, but WTO rules are applied with even greater flexibility. Although under agreements there is a ban on import quotas and approved binding tariff levels, GATT also allows anti-dumping and countervailing duties, subsidies as well as safeguard measures and includes an escape clause. Thanking them governments have easy access to all measures that can limit trade. So, the governments of many countries found it inappropriate to increase competition in a number of industries that play an important 
role in ensuring food security and national security of their own countries. This is why both developed and developing countries resorted to selective bans or restrictions on the import of goods. These measures increase the circulation costs of imported goods, which make them less competitive than domestic ones or create uncertain conditions in the import mechanism of these goods. To be mentioned that the last surge of protectionism took place in the first decade of the 21 century and was explained by post-crisis consequences of economic shock of 2008-2009 periods. According to researchers, it didn't result in much protectionism because of contemporary developed shock absorbers mechanisms (Bown, 2001; Douglas \& Kevin, 2011). Although still, trade protectionism is restricting the race of growth of world trade.

Since the early 2000s then WTO has achieved remarkable results in the liberalization of customs tariffs, their role, as internal market protection tools, logically diminished.

In accordance with trade management concept applied in the past century, simultaneously with the reduction of tariff barriers, the following trend was also manifested: increasing the use of different non-tariff limitations in foreign trade.

By the accepted definition in international trade practice, non-tariff barriers to trade are considered to be any measures taken by governments but different to tariffs that help to limit trade-offs between countries.

Compared with tariff barriers, non-tariff measures (NTMs) are often more difficult to detect. They are usually "hidden" in rules and practices that in fact can have a perfectly legitimate objective, but the economic effects of non-tariff barriers (NTBs) can be substantial in both positive and negative sense. The main reasons for the frequent application and use of these measures were generated by the domestic policies of each country. Trade negotiations between countries were driven mainly by the granting of market access "concessions". Consequently, countries diminished NTMs only when their partners weakened theirs.

At present high non-tariff barriers to trade in some key areas of the global economy are remain restricting trade.

Many experimental studies approved that regulatory NTMs are more predominate for agricultural trade than for non- agricultural.

Recent researches confirm also that developed countries more applied regulatory NTMs than developing ones. In contrast, tariff measures, which are more probably to constrain trade directly, are more widespread among low-income countries. (IMF, WB \& WTO, 2017, p.12)

Thanks to liberalization of customs tariffs, reducing of trade barriers as well as transport and communications costs has been changing global trade picture.

Latest trade facilitation which can be determinate as "the simplification, standardization, and harmonization of procedures and associated information flows required to move goods from seller to buyer and to make payment" (UNECE, 2012) has appeared as a key topic in agenda the world trading system.

As it is mentioned in WTO report 2015: "While trade agreements in the past were about "negative" integration - countries lowering tariff and non-tariff barriers - the WTO Trade Facilitation Agreement (TFA) is about positive integration - countries working together to simplify processes, share information, and cooperate on regulatory and policy goals" (WTO, 2015, p.32).

Last decades in the economic literature dedicated of trade topics have discussed the importance of trade liberalization for organizing the production of goods and adding value across different countries that consistently led to the appearance of global value chains (GVC). 
Under value chains according to M. Porter(1985) who primarily described this concept is understanding the division a firm into the discrete activities it performs in designing, producing, marketing, and distributing its product. This concept was used by him as the main tool for diagnosing competitive advantages by disaggregating the firm in the activities underlying the competitive advantage and identifying links between activities that are central to the competitive advantage and also explaining how coalitions with other firms can replace performance inside the chain.

Value chains have started in framework mainly of one country, then expanded to neighboring countries, have developed at the global level in the early 2000s. In global trade landscape where partners' exports depend on imports and where their connection to the world market is as effective as their link to any other link in the value chain, countries have a greater motivation to work together in order to reduce trade barriers, harmonize standards, costume procedure etc.

A number of recent studies contain important findings related to countries and firm's position in GVC.

The approach of international organizations is based on country and sectorlevel analyses to fragmentation of production. Several international organizations have developed a range of WEB simulation tools that allow estimating the value-added portion of a country's exports, among which are: Market Analysis Tools of International Trade Center (ITC) of the World Trade Organization and the United Nations, the Trade in Value Added (TiVA) instrument, developed by OECD for the comparative analysis of GVC integration across countries of different levels of development. It was demonstrated that export competitiveness presupposes import openness because foreign inputs lead to the domestic value-added portion of a country's exports.

In contrast with international organizations in many case studies have been emphasized that firm- and sector-level analysis is central to GVC approaches to fragmentation of production. It is also accentuated that unlike the value-added trade, there is no single, accepted standard among GVC economists on how to conceptualize, determine and estimate the value or its distribution among firms (Dallas, 2014).

Based at the analysis of the experimental findings, in the economic literature regarding this phenomenon is concluded, that since the early 1990s GVCs have become a strong driver of productivity and manufacturing exports and they are covering a wide range of goods from labor-intensive activity to high technology (IMF, WB \& WTO, 2017, p.8; OECD, 2018).

In this context was approved that countries' and firms' benefits do not rely on the kind of activity develop, but on the value generated for the economy, which can come from any type of activity in the framework of the chain (Lopez, 2016, p.10). So, countries' and firms' position are based on their competitive advantages and measure of effectiveness within the chain.

In the era of increasingly developing GVCs, innovation, and technology transfer are also seen as important sources of more sustained competitive advantage based on intangible assets rather than labor costs (Nolan \& Pilat, 2016).

Many studies emphasis positive correlation between the signing deeper agreements and GVC- related trade (Mattoo, Mulabdic \& Ruta, 2017; Osnago, Rocha \& Ruta, 2017).

EU membership countries are included into the group of countries with the deepest agreements. It should be noted that Agreement between Republic of Moldova and EU members is one of deepest. It covers 44 provisions in comparison with about 25 on average provisions in force in 2015, according to World Bank database documents. (Hofmann, Osnago \& Ruta, 2017) 
In this context, recent FTA between of Republic of Moldova and EU gives advantages domestic firms, taking in the attention the possibility for extension their activities in international networks of production and first of all in the EU.

In a country's research is mentioned that the valorification of this potential of FTA will allow to Moldova to overcome the disadvantages of the small country market by the creation of narrow specialization profiles in the production of many times greater than the needs of the domestic market, and even at all unrelated to them. Absorbing the innovations and technology transfer, thanks engagement in GVC, will conduce to overcome such deficiencies of domestic production as the insufficient competitiveness of Moldovan exports at the external markets as well as the failure to suggest a wide enough assortment of final consumption goods to them. (Dumitrasco, 2016)

In economic literature to complementary to above mentioned in the example of country's research emphasize following opportunities for developing countries from adhering to GVC. They can more rapidly than was possible in the previous industrialization period to integrate into the global economy by using their comparative advantage to concentrate on a specific production process or task. (Kowalski et al., 2015). They can also create more job opportunities becoming a part of GVCs (UNCTAD, 2013).

In many research regarding developing countries is mentioned that they are entering in GVC at the assembly and production stage and are mainly engaged in lowincome global value chains. In context, GVC researchers pointed out the limitations of developing countries in upgrading within fragmented production chains, especially taking in attention such factor of production as labor. Milberg and Winkler find that offshoring reduces employment and raises income inequality between countries and allows firms in developing countries to bring down domestic investment and focus on finance and short-run stock movements (Milberg \& Winkler, 2013). Development is associated with "upgrading" in global value chains, but this is not sufficient for improved wages or labor standards.

To be mentioned that for the rethinking of upgrading in global value chains is using the concept of "smile curve". It was first introduced by Shih on the example of the personal computer industry who noticed that at each end of the curve obtain higher value added to the product than in the middle (Shih, 1996). Therefore, at one end are concentrated preproduction activities such as R\&D, while on the other postproduction such as marketing. Both tend to obtain a higher share of final product and are situating in developed countries. In contrast, manufacturing or assembly activities in developing countries tend to be located in the middle of the curve that corresponds to lower valueadded share.

At present, the significance of GVCs for the CEFTA economies of Southeast Europe region is limited, because "they are only weakly to moderately integrated into international trade" (CEFTA Investment Report, 2017).

In the country's research also was demonstrated that goods from Moldova are insufficiently penetrated in income value chains. They mostly are related to items with a low value-added share that provided in the customs regime of inward processing trade with few European countries. The advantage of geographical approximation to Europe one of the main manufacturing hubs around of which is organized the GVC activity is practically unused by Moldova (Dumitrasco, 2016; Dumitrasco, 2017).

OECD study (2015) paid attention to the necessary the adoption of economic policies that can help developing countries improve their competitiveness for integration in GVC. 


\section{Methodological background and objectives of the research}

Innovation competitiveness of a country is the main determinant for successful integration of countries in the $\mathrm{GVC}$, as can be concluded from analysis of literature review.

The study is based on the analysis of the Republic of Moldova's score and position in international indicators and rankings in correlation with the methodology of the World Economic Forum. Understanding the factors of competitiveness in framework of this methodology is arising from theories of specialization and the division of labor to neoclassical theories emphasis on investment in physical capital and infrastructure, and, later, to interest in other mechanisms such as education and training, technological progress, macroeconomic stability, good governance, firm sophistication, and market efficiency (Global Competitiveness Report, 2014-2015). All listed facilitate integration of country in the value chains.

Although researchers pay a special attention to the analysis of indicators included in sub index "Innovation and sophistication factors" (Krstić \& Krstić, 2015), first of all will be specified most critical indicators of Global Competitiveness Index for economy of Republic of Moldova, taking in consideration interconnection between 12 pillars of competitiveness as well as the actual level of economic development of country.

In Global Competitiveness Report (2011-2012) is mentioned: "While all of these factors are likely to be important for competitiveness and growth, they are not mutually exclusive - two or more of them can be significant at the same time".

In this context, in line with innovation and sophistication factors, the technological readiness indicator closely associated with the innovation competitiveness of the country is included in the analysis.

For the purpose of research, it is important to compare the score of indicators covered by sub index "Innovation and sophistication factors" with indicators of other two sub-indexes.

Analysis below embraces indicators included in the World Economic Forum the Global Competitiveness reports from 2011 to 2017; their average scores there it was is applicable as well as growth rates of indicators of innovation and business sophistication and technological readiness competitiveness of Moldovan economy calculated by the author for the mentioned period.

It should be noted that in accordance with the methodology applied, for the economies which are measured in the overall GCI below 50, any individual performance measured above 51, are considered advantages (Global Competitiveness Report, 2011-2012, p. 90).

The growing interest of Moldovan government to the country's score and position in international indicators and rankings was manifested recently by the introduction of their mandatory monitoring in all key ministers as well as the elaboration of amelioration proposals (Government decision Nr.297 from 30 March 2018). It is explained by the importance of country's score and position for the decisions of foreign investors. So, our research should have applied character. For completeness, the analysis is supplemented by an analysis of national statistics.

Based on the methodology, there are following objectives of the study:

- Establishing the key domains for the improvement of country's competitiveness,

- Determining the most problematic factors that affecting the innovation and business sophistication factors competitiveness of the Moldovan economy, taking into attention the necessity of adopting the urgent economic policy measures, 
- Comparing the values of innovation, business sophistication and technological readiness factors of competitiveness between Moldova and South-Eastern Europe countries, with the scope of the estimation the convergence within countries.

\section{Records of the innovational competitiveness of the Moldovan economy}

According to the stage of development, the economy of Moldova balanced between factor-driven and efficiency-driven in framework analyzed period 2011-2017. It was classified as efficiency-driven in the period 2013-2015. While in the remaining years it was classified as the factor-driven economy. Although the low progress was demonstrated by Moldovan economy, the pillars included in sub index "Basic requirements" (4.2 average score) are ranking higher than those in sub index "Efficiency enhancers" (3.7) as well as in sub index "Innovation and sophistication factors" (2.9) (Table 1)

Table 1 Most critical indicators of Global Competitiveness Index for the economy of Republic of Moldova

\begin{tabular}{|c|c|c|c|c|c|c|c|c|c|}
\hline Subindex and pillars & Year & 2011 & 2012 & 2013 & 2014 & 2015 & 2016 & 2017 & $\begin{array}{c}\text { Average } \\
\text { score }\end{array}$ \\
\hline \multirow{2}{*}{$\begin{array}{l}\text { Basic requirements - } \\
\text { total, from which: }\end{array}$} & score & 4.1 & 4.2 & 4.2 & 4.3 & 4.3 & 4.1 & 4.2 & 4.2 \\
\hline & rank & 102 & 93 & 97 & 90 & 89 & 101 & 95 & \\
\hline \multirow[t]{2}{*}{ Institutions } & score & 3.4 & 3.4 & 3.2 & 3.2 & 3.2 & 3.1 & 3.2 & 3.2 \\
\hline & rank & 106 & 110 & 122 & 121 & 123 & 128 & 119 & \\
\hline \multirow{2}{*}{$\begin{array}{l}\text { A. Efficiency } \\
\text { enhancers - total, from } \\
\text { which: }\end{array}$} & score & 3.6 & 3.7 & 3.7 & 3.8 & 3.8 & 3.7 & 3.7 & 3.7 \\
\hline & rank & 103 & 99 & 102 & 88 & 94 & 102 & 94 & \\
\hline \multirow{2}{*}{$\begin{array}{l}\text { Financial market } \\
\text { development }\end{array}$} & score & 3.6 & 3.6 & 3.6 & 3.7 & 3.3 & 3 & 3.1 & 3.4 \\
\hline & rank & 105 & 104 & 105 & 100 & 115 & 129 & 124 & \\
\hline \multirow{2}{*}{$\begin{array}{l}\text { B. Innovation and } \\
\text { sophistication factors } \\
\text { - total, from which: }\end{array}$} & score & 2.9 & 2.9 & 2.9 & 2.9 & 2.9 & 2.9 & 3 & 2.9 \\
\hline & rank & 127 & 131 & 133 & 129 & 128 & 131 & 124 & \\
\hline \multirow{2}{*}{$\begin{array}{l}\text { Business } \\
\text { sophistication }\end{array}$} & score & 3.3 & 3.3 & 3.3 & 3.4 & 3.3 & 3.2 & 3.4 & 3.3 \\
\hline & rank & 117 & 120 & 125 & 124 & 127 & 127 & 120 & \\
\hline \multirow[t]{2}{*}{ Innovation } & score & 2.4 & 2.4 & 2.4 & 2.5 & 2.6 & 2.5 & 2.6 & 2.5 \\
\hline & rank & 128 & 135 & 138 & 131 & 130 & 133 & 128 & \\
\hline
\end{tabular}

Source: Elaborated by the author at the WEF, the Global Competitiveness Report, 2011-2012 to 2017-2018

It can be also observed that only on the groups of basic requirements and efficiency enhancers, the country was placed above the hundredth position during some years.

In the framework of subindexes, the lowest score is obtained by indicators of innovation pillar (2.5 average value), the institution's pillar (3.2), the financial market development (3.4) and the business sophistication pillar (3.3). 
To be mentioned that in the sub index "Innovation and sophistication factors" both pillars groped in it were mentioned as critical taking attention their equal weight within sub index, besides the values reached.

Despite the growing scores at the end in comparison with the beginning analyzed period, the annual indicators of the innovational competitiveness show very little progress. The best position occupied by country is the 128 place or is among the last ten countries included in the list.

Although the business sophistication indicators are classified higher than innovational once, they demonstrate a moderate performance the same, with the position in the latest twenty countries in the world.

The scores and ranks of Institutions and financial market development pillars testify the regress of indicators of competitiveness in recent years in comparison with the beginning of the period.

Moldova's situation in Southeast Europe, along with the eastern border of the European Union, is stipulated its participation in the initiatives on the regional level that are aimed at making the region more competitive on the global landscape as well as reaching greater matching between countries.

In this context, the comparative analysis below covers Moldova and six countries of Southeast Europe region with the point of view their innovation environment competitiveness as well as the technological readiness.

It should be noted that economy of Republic of Moldova was behind the countries of Southeast Europe in terms of the factors of innovation and sophistication competitiveness during analyzed period (Table 2).

Table 2 Evolution of the innovation and sophistication factors competitiveness of some Southeast Europe countries for the period 2011-2017

\begin{tabular}{|c|c|c|c|c|c|c|c|c|c|}
\hline Countries & Year & 2011 & 2012 & 2013 & 2014 & 2015 & 2016 & 2017 & $\begin{array}{c}\text { Average } \\
\text { score }\end{array}$ \\
\hline \multirow{3}{*}{ Moldova } & score & 2.9 & 2.9 & 2.9 & 2.9 & 2.9 & 2.9 & 3 & 2.9 \\
\cline { 2 - 11 } & rank & 127 & 131 & 133 & 129 & 128 & 131 & 124 & \\
\hline \multirow{3}{*}{ Romania } & score & 3.2 & 3.2 & 3.3 & 3.5 & 3.5 & 3.3 & 3.3 & 3.3 \\
\cline { 2 - 12 } & rank & 99 & 106 & 103 & 78 & 89 & 100 & 107 & \\
\hline \multirow{3}{*}{ Bulgaria } & score & 3.2 & 3.3 & 3.3 & 3.3 & 3.4 & 3.6 & 3.6 & 3.4 \\
\cline { 2 - 12 } & rank & 96 & 97 & 108 & 106 & 94 & 71 & 73 & \\
\hline \multirow{3}{*}{ Albania } & score & 3.2 & 3.1 & 3.1 & 3.2 & 3.2 & 3.3 & 3.6 & 3.2 \\
\cline { 2 - 11 } & rank & 102 & 113 & 119 & 114 & 115 & 106 & 76 & \\
\hline \multirow{3}{*}{ Croatia } & score & 3.4 & 3.4 & 3.5 & 3.5 & 3.4 & 3.4 & 3.4 & 3.4 \\
\cline { 2 - 11 } & rank & 82 & 83 & 80 & 87 & 90 & 92 & 99 & \\
\hline \multirow{2}{*}{ Serbia } & score & 3.0 & 3.0 & 3,0 & 3.1 & 3.0 & 3.1 & 3.3 & 3.1 \\
\cline { 2 - 10 } & rank & 118 & 124 & 125 & 121 & 125 & 120 & 104 & \\
\hline \multirow{2}{*}{ Montenegro } & score & 3.6 & 3.6 & 3.6 & 3.5 & 3.4 & 3.4 & 3.4 & 3.5 \\
\cline { 2 - 10 } & rank & 59 & 69 & 70 & 77 & 86 & 98 & 92 & \\
\hline
\end{tabular}

Source: Elaborated by the author at the WEF, the Global Competitiveness Report, 2011-2012 to 2017-2018 
It can be observed also that the factors of competitiveness were estimated with annual score 2.9 in the framework of the observed period with the exception 2017 year (3.0), that notes absent of the progress practically in innovation and business sophistication sphere.

Similar, Serbia has demonstrated low innovation and sophistication competitiveness in comparison with countries of the region (Krstić \& Krstić, 2018). Indicators of competitiveness have fluctuated between 3.0-3.1 score with the exception of the 2017 year (3.3).

Untypically Montenegro exceeded the countries members of EU included in the analysis of innovation and sophistication competitiveness, obtaining the highest average score -3.5 . Although the records indicate a decrease of competitiveness the corresponding factors at the end of analyzed period comparing the beginning.

Croatia has insignificant changes in its factors of innovation and sophistication competitiveness, achieved the average score -3.4 .

The economies of Bulgaria and Albania have a favorable tend to increase their competitiveness in the relevant indicators.

There are no big breaks in the innovation competitiveness of the Southeast Europe countries in general. In 2017 all countries were classified in score diapason between 3.0 and 3.6.

In contrast, the evolution of technological readiness of the Southeast Europe countries shows the persistent competitiveness gaps between countries as measured by the GCI indicator (Figure 1).

Figure 1 Dynamics of the technological readiness of some Southeast Europe countries for the period 2011-2017

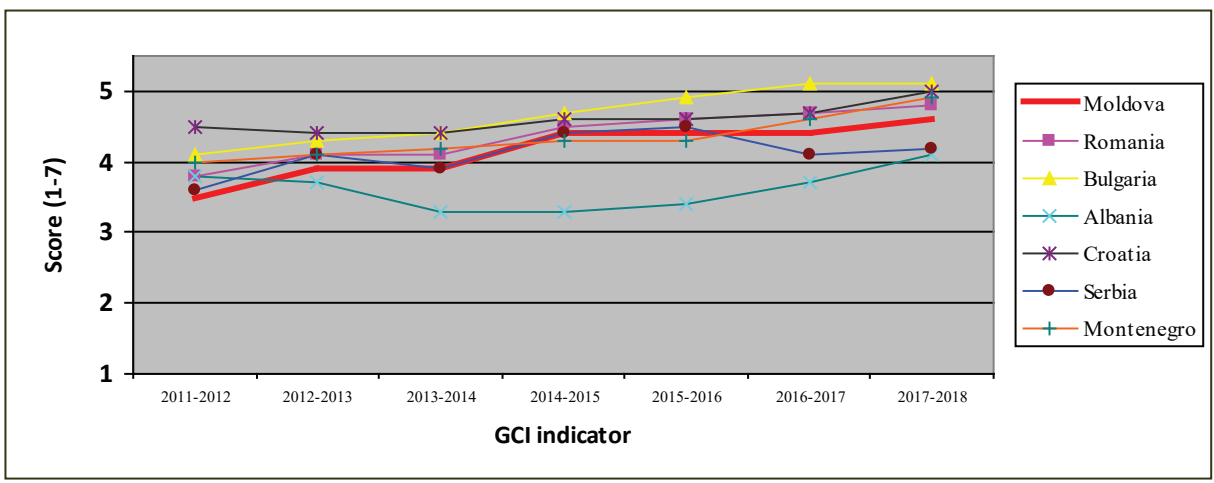

Source: Elaborated by the author at the WEF, the Global Competitiveness Report, 2011-2012 to 2017-2018

It can be observed also that in the top of technological readiness competitiveness is an economy of Bulgaria that obtained the score of 5.1 in both 2016 and 2017 years but in the bottom of Albania that received the score 3.7 and 4.1 respectively. In plus beginning with 2014, all analyzed economies have received the score more than 4 items, excepting the Albanian economy. 
It is important to emphasize that Bulgaria has had the competitive advantage in technological readiness (2013-2015) and Croatia (2013-2017). Both were ranking higher than the fiftieth place in technological readiness in the mentioned periods while their economies were ranked lower than fiftieth positions in the overall GCI.

Economies of Moldova and Serbia have demonstrated the similar records in 20132015 years in technological readiness, following the Romanian economy.

It should be noted that Moldova has overcome the Albanian economy as well the Serbian economy on the technological readiness of competitiveness in the last years. There is the lack of convergence within countries regarding on the technological readiness of competitiveness.

In the following analysis, the factors of innovation, business sophistication and technological readiness competitiveness of the Moldovan economy are studied in detail.

In the framework of business sophistication pillar, the factors of state of cluster development have demonstrated the catastrophic values occupying the latest positions in the world in the period 2014-2016 years, but in the rest years, one of the last places (Table 3).

Table 3 Factors of innovation, sophistication and technological readiness competitiveness of the Moldovan economy and their growth rate for the period 2011-2017

\begin{tabular}{|c|c|c|c|c|c|c|c|c|c|c|c|c|c|c|c|}
\hline \multirow[b]{2}{*}{ Factors } & \multicolumn{2}{|c|}{2011} & \multicolumn{2}{|c|}{2012} & \multicolumn{2}{|c|}{2013} & \multicolumn{2}{|c|}{2014} & \multicolumn{2}{|c|}{2015} & \multicolumn{2}{|c|}{2016} & \multicolumn{2}{|c|}{2017} & \multirow{2}{*}{$\begin{array}{c}\text { Growth } \\
\text { rate, \% } \\
\text { based } \\
\text { on the GCI } \\
\text { indicators }\end{array}$} \\
\hline & 范 & 弟 & 范 & 䮈 & 总 & 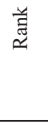 & 范 & 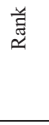 & 总 & 煎 & 总 & 臨 & : & 羊 & \\
\hline \multicolumn{16}{|c|}{ Business sophistication pillar } \\
\hline Local supplier quantity & 4 & 127 & 3.9 & 130 & 3.9 & 127 & 3.9 & 123 & 3.7 & 126 & 3.6 & 128 & 3.8 & 121 & -0.85 \\
\hline Local supplier quality & 3.8 & 117 & 3.8 & 117 & 3.8 & 115 & 3.8 & 113 & 3.7 & 115 & 3.7 & 113 & $3, .9$ & 100 & 0,4 \\
\hline $\begin{array}{l}\text { State of cluster } \\
\text { development }\end{array}$ & 2.4 & 132 & 2.4 & 140 & 2.3 & 147 & 2.4 & 144 & 2.3 & 140 & 2.3 & 138 & 2.6 & 134 & 1,3 \\
\hline $\begin{array}{l}\text { Nature of competitive } \\
\text { advantage }\end{array}$ & 2.9 & 109 & 3 & 106 & 2.8 & 127 & 2.6 & 131 & 2.6 & 130 & 2.4 & 130 & 2.4 & 126 & -3.1 \\
\hline Value chain breadth & 3.3 & 92 & 3.1 & 109 & 3.2 & 118 & 3.4 & 105 & 3.5 & 97 & 3.3 & 115 & 3.3 & 110 & 0 \\
\hline $\begin{array}{l}\text { Control of } \\
\text { international } \\
\text { distribution }\end{array}$ & 3.7 & 98 & 3.6 & 106 & 3.7 & 110 & 3.7 & 108 & 3.3 & 112 & 2.9 & 124 & 3 & 120 & -3.4 \\
\hline $\begin{array}{l}\text { Production process } \\
\text { sophistication }\end{array}$ & 2.8 & 122 & 2.8 & 121 & 2.9 & 125 & 3.1 & 122 & 3.1 & 114 & 3.1 & 113 & 3.2 & 106 & 2,3 \\
\hline Extent of marketing & 3.4 & 111 & 3.5 & 108 & 3.7 & 105 & 3.8 & 90 & 3.9 & 103 & 3.9 & 117 & 4 & 109 & 2.7 \\
\hline $\begin{array}{l}\text { Willingness to } \\
\text { delegate authority }\end{array}$ & 3.1 & 114 & 3.3 & 100 & 3.4 & 108 & 3.4 & 100 & 3.4 & 100 & 3.4 & 99 & 3.9 & 105 & 3.9 \\
\hline \multicolumn{16}{|c|}{$\mathrm{R} \& \mathrm{D}$ Innovation pillar } \\
\hline \begin{tabular}{|l|} 
Capacity for innovation \\
\end{tabular} & 2.6 & 107 & 2.5 & 122 & 2.7 & 134 & 3.0 & 128 & 3.4 & 115 & 3.5 & 124 & 3.4 & 119 & 4.6 \\
\hline $\begin{array}{l}\text { Quality of scientific } \\
\text { research institutions }\end{array}$ & 2.7 & 122 & 2.4 & 133 & 2.6 & 132 & 2.7 & 121 & 2.7 & 124 & 2.8 & 125 & 2.9 & 115 & 1,2 \\
\hline
\end{tabular}




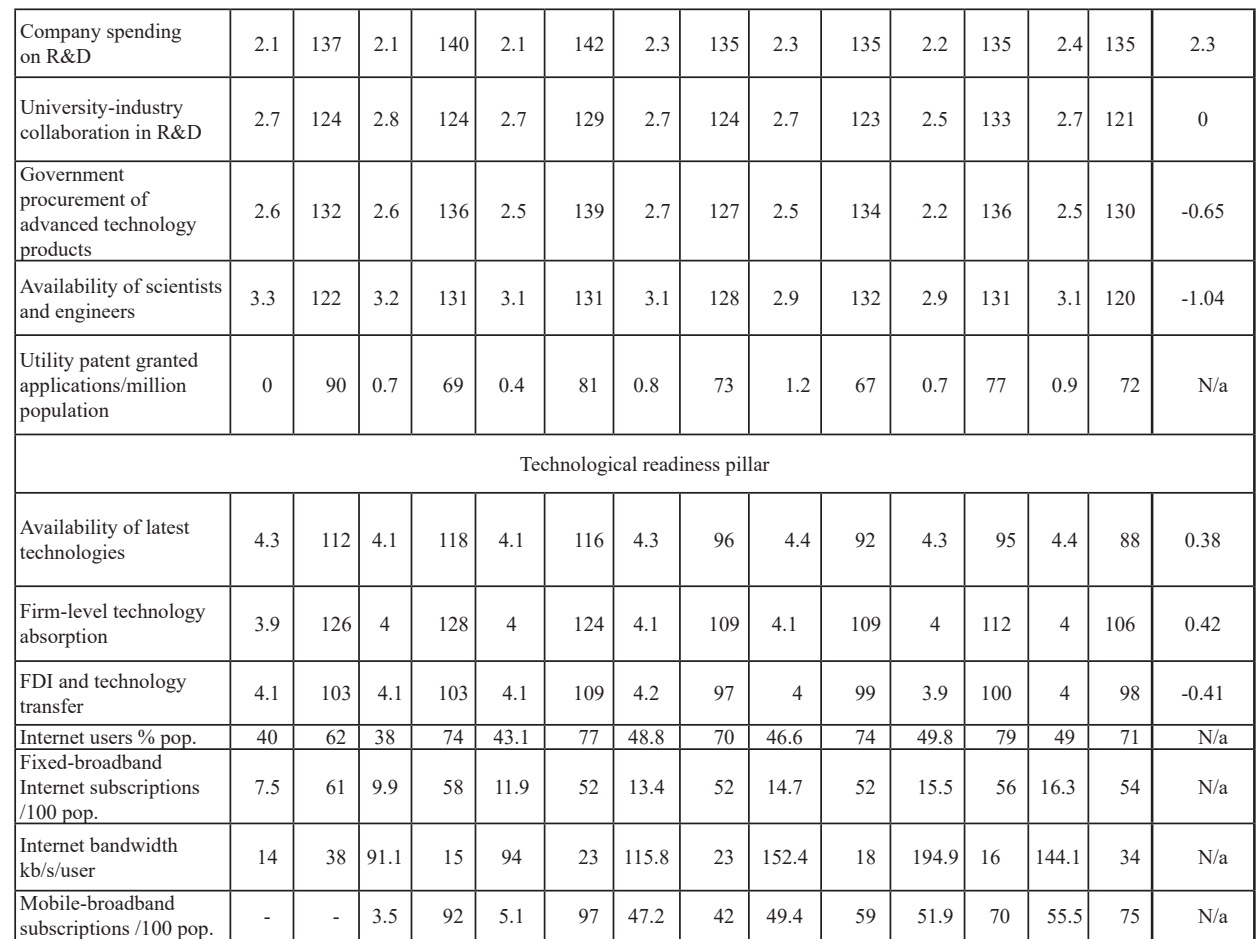

Source: WEF, the Global Competitiveness Report, 2011-2012 to 2017-2018

It speaks about the weak the horizontal inter-firm cooperation in the framework of the geographically approximate regions and the ineffective support by the public institutions the cluster development. Notwithstanding the growth of the state of cluster development (1.3\% annually), the initial comparison base was very low. So, current growth rates are not sufficient for intensify of the production process.

An attention is also drawn to the low values of the factors of nature of competitive advantage, which tend to decrease with significant average annual decline $(-3.1 \%)$. In context to be mentioned that the cheap labor force is the basis of competitive advantage of the country. At present, the lack of skilled workforce, linked to current and future market demands, is transformed into a one of a key obstacle to the development of small and medium business for the Republic of Moldova.

Scores of the indicators of the local suppliers' quantity and quality were correlated between themselves by supporting a relatively high growth of the production process sophistication of firms $(2.3 \%$ annually) and extent of marketing $(2.74 \%$ per year). The quality of individual firm's operations and strategies is characterized also by the willingness to delegate the authority by senior management to subordinates had the highest growth rate (3.9\% annually) between the factors of business sophistication pillar. Moldova's firms do not expand its participation in value chains ( $0 \%$ annual growth). The country is placed lower than hundredth (2012-2017) at the bottom of GVC. In plus, the control of international distribution is decreasing in the small economy of Moldova with significant average annual decline $(-3.4 \%)$. 
The country is lagging quite far behind in terms of innovation factors as well as business sophistication. Utility patent granted applications have the highest rating between of factors of innovation pillar (seventy-second place in 2017).

Innovation capacity is assessed as significantly increasing (4.57\%) supported by the average annual company spending on $R \& D-2.25 \%$. At the same time, the initial reference base was very low. The best score for capacity for innovation was one hundred seventh (2011). The best position of the Republic of Moldova on the company spending on R\&D was one hundred thirty-fifth rank (2014-2017), that is one of the latest places in the world. University-industry collaboration in R\&D is not expanded $(0 \%$ annual growth). Quality of scientific research institutions is changed slowly (1.2\% per year). Government procurement of advanced technology products fall in average $(-0.65 \%$ per year). Availability of scientists and engineers also tends to decline (-1.4\% annually).

Whereas indicators of technological readiness pillar are ranking the highest in front of business sophistication and innovation pillars they are developed unevenly.

On the one side, Moldova had the competitive advantage in the Internet bandwidth, ranking higher than the fiftieth place (the best - the fifteen in 2012), taking into attention that economy was ranked lower than fiftieth positions in the overall GCI during the analyzed period. Fixed-broadband internet subscriptions should be considered as the upgrading factor with the best rank fifty-second in 2013-2015 years. Also, it has room for improvement.

On the other side, the highest rank of the firm-level technology absorption was one hundred sixth grade as well as the availability of latest technologies - eighty-eight, both obtained in 2017 . They show a similar very low average annual growth. The first mentioned factor $-0.42 \%$, but the second one $-0.38 \%$.

Finally, FDI and technology transfer is characterized by an average annual deterioration (-0.41). At present, there is not only a general shortage of export-oriented FDI in highertechnology industries but the weak correlation between them (Dumitrasco, 2015).

There is in decline the financing of the projects the technology transfer from internal sources of the country in the last years in compare with 2011-2014 (Figure 2).

Figure2. Dynamic of financing of the projects the technology transfers in the years 2011-2017, thousand Moldovan lei

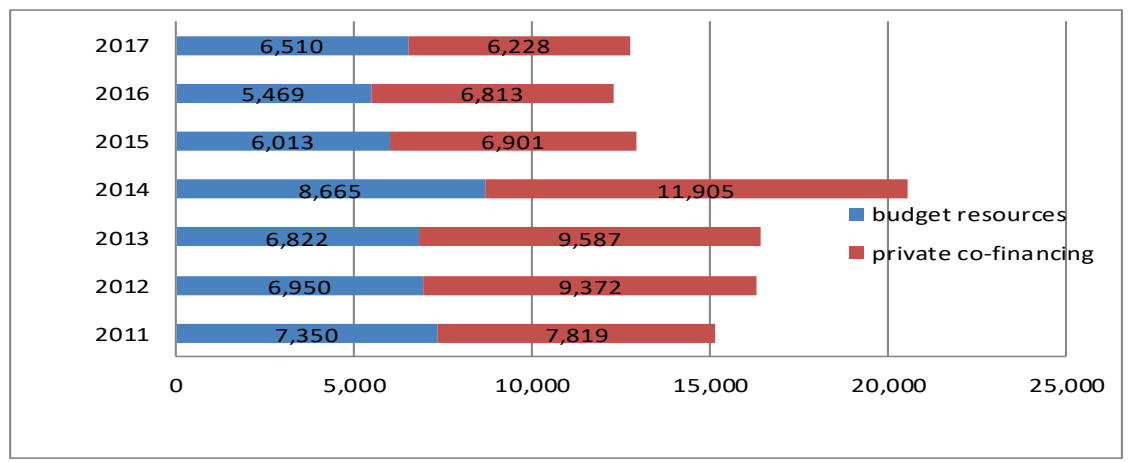

Source: Elaborated by the author based on the Report on the activity of Supreme Council for Science and Technological Development and the main scientific results obtained in the sphere of science and innovation in 2017 
In period 2011-2017 the Agency for Innovation and Technology Transfer of the Academy of Sciences of Moldova managed the innovation and technology transfer projects, financed from the state budget and private sources in proportion $50 \%$ to $50 \%$ of the total cost of the project. The mandatory condition for the implementation of the innovation and technology transfer projects was the implementation of a new innovation or technology for the Republic of Moldova. Innovation and technology transfer projects is a tool to stimulate innovation in SMEs by partially taking over the risks of this innovation by the government authority. At the same time, innovation and technology transfer projects represent a form of transmission of new technologies from the research institutions to the innovation firms, their multiplication, and application at the level of industry, having as affect the development of domestic innovation firms by producing new competitive products on the internal and the external markets.

Reducing of financing of the projects the technology transfer is explained by the limitation of resources from the state budget as well as difficulty to find co-financing from the side of the private firm because of the low university-industry collaboration in $\mathrm{R} \& \mathrm{D}$, as it was mentioned earlier.

\section{Conclusion}

This study showed that the Republic of Moldova has disadvantageous indicators of innovation and business sophistication competitiveness.

The areas of business sophistication and innovation are characterized by a low availability of scientists and engineers, and university-industry collaboration in R\&D, an unfavorable situation in the government procurement of advanced technology products as well as insufficient company spending on $R \& D$ and quality of scientific research institutions.

At the same times, some indicators dealing with quality of individual firm's operations and strategies have demonstrated the growth rates, including production process sophistication, the success of companies in using of marketing; capacity to commercialize new products; company spending on R\&D; firm-level technology absorption; willingness to delegate the authority. The study found also while efforts by the firms have tended to arise, they are not supported enough by the measures of state policy regarding the quality of a country's overall business networks. First of all it concerns to the government support of the cluster development (latest positions in the world in 2014-2016), the expanding of participation in value chains ( $0 \%$ annual growth), the quantity of local suppliers ( $-0.85 \%$ annual average fall); government procurement of advanced technology products ( $-0.65 \%$ annual average decline).

Nature of competitive advantage based on the cheap labor force enters into the stage of disappearance. In plus, the availability of scientists and engineers also tends to decline. Hence it should be adopted necessary measures of state politics in the field of education and the labor market.

The study found the low level of FDI inflows into the higher-value manufacturing and tradable sectors, that tend to decline. While internal sources of the country from the state budget and domestic firms are limited. To change this situation for the better is also required the state intervention.

So, the competitiveness of the economy of Moldova is largely predetermined by the development of state institutions and the financial market which study found between one of the most problematic indicators. 
In contrast, access to Information communication technologies (ICT)is relatively high in Moldova. About $50 \%$ of populations are the Internet users. According to Internet bandwidth, Moldova has a competitive advantage. Fixed-broadband internet subscriptions also demonstrate high records.

The advanced ICT services may attract future FDI, as several foreign companies are already successful in these sectors in the economy of the Republic of Moldova. The country should also use the entering' opportunities: either through joining existing value chains or by finding niches in the ICT services.

In the regional aspect study displayed that the economy of Serbia has demonstrated similar Moldova's records in technological readiness as well as they are comparable in the factors of innovation, business sophistication competitiveness.

Finally, the study identified that the Republic of Moldova has lowest indicators of the innovation and sophistication competitiveness in comparison with other countries of Southeast Europe, but the economy of Moldova follows the EU economies on the technological readiness.

\section{References}

Bown, C. (2001). The Great Recession and Import Protection: The Role of Temporary Trade Barriers. Washington, The World Bank.

Bustos, P. (2011). Trade Liberalization, Exports and Technology Upgrading: Evidence on the impact of MERCOSUR on Argentinian Firms. American Economic Review, 101 (1): 304-340.

Cassiman, B., Golovko, E., \& Martínez-Ros, E. (2010). Innovation, exports, and productivity. International Journal of Industrial Organization, 28: 372-376.

CEFTA Investment Report (2017), prepared by Gabor Hunya, Senior Expert at the Vienna Institute for International Studies, within the framework of the CEFTA Secretariat Project CPF III: 2016-10: Technical Assistance for the Preparation of CEFTA Investment Report

Douglas, A.,\& Kevin H. O'Rourke NBER Working Paper No. 17598 (November 2011) Coping with Shocks and Shifts: , The Multilateral Trading System in Historical Perspective, available at: http://www.nber.org/papers/w17598.pdf

Dumitrasco, M. (2015). Overview of Approach Based on Links Between Trade Exchange and Innovation. In B. Krstic \& Z. Paszek (Eds.), The determinants of competitiveness (pp. 71-75). Nis, Serbia: Faculty of economics.

Dumitrasco, M. (2016, June). Engagement of the Republic of Moldova in external fragmentation of production in framework Paper presented at the conference: "Europe adrift. From unity in diversity to diversity without unity", University Petrol-Gaze, Romania.

Dumitrasco, M. (2017). Involvement of local products of technological intensity in external fragmentation of production: the case of the Republic of Moldova. In B. Krstic \& Z. Paszek (Eds.), Improving micro and macro competitiveness - problems and possible solutions (pp. 201-221). University of Niš, Serbia: Faculty of economics 
Government decision Nr. 297 from 30 March 2018, "On completing of some Government decisions"

Hofmann, C., Osnago, A., Ruta, M. (2017). Horizontal depth: a new database on the content of preferential trade agreements. Washington, World Bank Group.

Kowalski, P. et al. (2015). Participation of Developing Countries in Global Value Chains: Implications for Trade and Trade-Related Policies. Paris, OECD Publishing.

Krstić, B., \& Krstić, M. (2015). Determinants of national economy competitiveness of Balkan countries - benchmarking study. In B. Krstic \& Z. Paszek (Eds.), Competitiveness of enterprises and national economies (pp. 1-17), Niš, Serbia: Faculty of Economics.

Krstić, B., \& Krstić, M. (2015). A science as the determinant of competitiveness of countries - benchmarking study. In B. Krstic (Ed.), Enchancing the Efficiency and Competitiveness of Enterprises and National Economies - problems, factors, determinants, strategies and solutions (pp. 1-25), Niš, Serbia: Faculty of Economics.

Lopez, G. (2016). Using Foreign Factors to Enhance Domestic Export Performance: A Focus on Southeast Asia. Paris, OECD Publishing.

Making Trade an Engine of Growth for All the Case for Trade and for Policies to Facilitate Adjustment. Report prepared by the staff of International Monetary Fund, World Bank, and World Trade Organization, for discussion at the meeting of G20 SHERPAS, March 23-24, 2017 Frankfurt, Germany

Mark, D. (2014). Governed Trade: Global Value Chains, Firms and the Heterogeneity of Trade in an Era of Fragmented Production. Review of International Political Economy, 22 (5):875-909.

Mattoo, A., Mulabdic A., \& Ruta, M. (2017). Trade Creation and Trade Diversion in Deep Agreements. Washington, World Bank

Milberg, W., \& Winkler, D. (2013). Outsourcing Economics: Global Value Chains in Capitalist Development. Cambridge, Cambridge University Press.

Nolan, A., \& Pilat, D. (2016). Benefitting from the Next Product revolution. Paris, OECD Insights.

OECD (2015) Inclusive Global Value Chains Policy options in trade and complementary areas for GVC integration by small and medium enterprises and low-income developing countries OECD and World Bank Group. Report prepared for submission to G20 Trade Ministers Meeting Istanbul, Turkey, 6 October 2015

OECD (2018) Productivity and Jobs in a Globalised World (How) Can All Regions Benefit?, DOI: http://dx.doi.org/10.1787/9789264293137-en

Osnago, A., Rocha, N., \& Ruta, M. (2017). Deep Trade Agreements and Global Value Chains, Washington, World Bank.

Porter, M.E. (1985). Competitive Advantage. New York, Free Press. 
Report on the activity of Supreme Council for Science and Technological Development and the main scientific results obtained in the sphere of science and innovation in 2017. Available at: http://www.asm.md/administrator/fisiere/rapoarte/f176.pdf

Shih, S. (1996). Me-Too is Not My Style: Challenge Difficulties, Break through Bottlenecks, Create Values. Taipei, The Acer Foundation.

Schwab, K. (2012). The Global Competitiveness Report 2011-2012. Geneva, World Economic Forum.

Schwab, K. (2013). The Global Competitiveness Report 2012-2013. Geneva, World Economic Forum.

Schwab, K. (2014). The Global Competitiveness Report 2013-2014. Geneva, World Economic Forum.

Schwab, K. (2015). The Global Competitiveness Report 2014-2015. Geneva, World Economic Forum.

Schwab, K. (2016). The Global Competitiveness Report 2015-2016. Geneva, World Economic Forum.

Schwab, K. (2017). The Global Competitiveness Report 2016-2017. Geneva, World Economic Forum.

Trade Facilitation Implementation Guide: United Nations Economic Commission for Europe (UNECE, 2012). Retrieved March 20, 2018 from http://tfig.unece.org/ details.html

UNCTAD (2013, advance unedited version) Global Value Chains And Development (Investment and value added. Trade in the global economy). A preliminary analysis.

WTO (2015) Speeding up trade: benefits and challenges of implementing the WTO Trade Facilitation Agreement. 